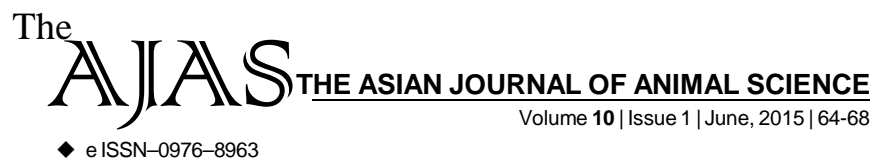

DOI : 10.15740/HAS/TAJAS/10.1/64-68 Visit us | www.researchjournal.co.in $\mathrm{S}$

RESEARCH ARTICLE.

\title{
Comparative study on the effect of ovaprim and Wova-FH on induced breeding response on Anabas testudineus (Bloch)
}

\author{
ATOM ARUN SINGH, SAUMYENDRA NANDA, NIKHIL KUMAR MOHARANA AND SUCHISMITA \\ PRIYADARSINI
}

Author for Corresponding -

\section{SAUMYENDRA NANDA}

P.G. Department of Aquaculture, College of Fisheries (O.U.A.T.),

Rangailunda, BERHAMPUR (ODISHA) INDIA

Email: saumyendra.nanda@ rediffmail.com

See end of the article for Coopted authors'

\begin{abstract}
The present investigation was carried out for comparative evaluation of two commonly used synthetic hormones ovaprim and Wova-FH on induced breeding response of Anabas testudineus (Bloch). Both the hormones are administered at a rate of 0.2, 0.3 and 0.4 $\mathrm{ml} / \mathrm{kg}$ body weight of the fish to find out their effect on breeding response, latency period, quantity of eggs released, fertilization and hatching rate. The study reveals that, both the inducing agents administered at a rate of $0.4 \mathrm{ml} / \mathrm{kg}$ body weight to Anabas testudineus resulted with complete spawning. The fertilization and hatching percentages were reported to be more when brooders are administered with ovaprim than that of Wova-FH. The study further indicates a strong correlation to exist between the doses of ovaprim with egg output $(+0.99)$, fertilization rate $(+0.99)$, hatching rate $(+0.99)$, spawn production $(+0.99)$. A negative correlation was reported to exist between the doses of ovaprim with latency period (-0.99) and hatching time $(-0.90)$ which indicates that, with increase in the concentration of ovaprim the latency period and hatching time decreases.
\end{abstract}

KEY WORDS...... Ovaprim, Wova-FH, Induced spawning, Latency period, Fertilization percentage, Hatching percentage

HOW TO CITE THIS ARTICLE - Singh, Atom Arun, Nanda, Saumyendra, Moharana, Nikhil Kumar and Priyadarsini, Suchismita (2015). Comparative study on the effect of ovaprim and Wova-FH on induced breeding response on Anabas testudineus (Bloch). Asian J. Animal Sci., 10(1) : 64-68.

ARTICLE CHRONICLE - Received : 25.04.2015; Revised : 07.05.2015; Accepted : 21.05.2015 